\title{
PEMASARAN ONLINE PRODUK OLAHAN UNIK AMPAS TAHU SEBAGAI BENTUK DIVERSIFIKASI PRODUK MENGGUNAKAN HASIL PROSES PENGOLAHAN LIMBAH SEDERHANA INDUSTRI TAHU
}

\author{
Ivon Sandya Sari Putri ${ }^{1}$, Dini Rahmawati ${ }^{1}$, Nila Novita Sari ${ }^{1}$ \\ ${ }^{1}$ Politeknik Negeri Bandung
}

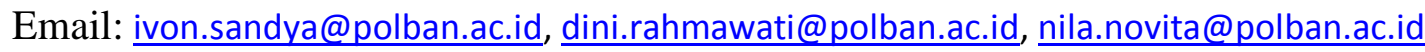

\begin{abstract}
Abstrak
Industri pengolahan makanan, merupakan salah satu sektor unggulan Kota Cimahi yang menyumbang sekitar $46.8 \%$ ekonomi masyarakat. Menurut data dari Dinas Perdagangan, Koperasi, UKM dan Perindustrian Kota Cimahi, industri rumah tangga dalam hal pengolahan tahu/ tempe di tingkat rumah tangga mencapai 29,63\%. Seperti halnya industri lain, industri pengolahan tahu menghasilkan limbah yaitu limbah cair dan padat, yaitu ampas tahu. Ampas tahu yang dihasilkan saat ini masih mengandung air yang cukup banyak yang dapat menimbulkan bau tidak sedap bila disimpan lama. Pemanfaatan limbah ampas tahu ini pun belum maksimal. Kegiatan ini memberikan pelatihan kepada pelaku industri tahu untuk bisa mengurangi kadar air dalam pengolahan ampas tahu sehingga ampas tahu yang dihasilkan dapat dimanfaatkan lebih maksimal, salah satunya menjadi produk olahan unik nugget ampas tahu sebagai bentuk diversifikasi produk. Tidak hanya itu, kegiatan ini juga memberikan pelatihan mengenai bagaimana cara untuk memasarkan produk nugget ampas tahu secara online untuk bisa menutupi kekurangan sumber daya waktu dan manusia.
\end{abstract}

Kata kunci: Pengolahan limbah tahu, Diversifikasi produk, Industri tahu

\section{PENDAHULUAN}

Tahu merupakan salah satu pangan yang mempunyai nilai gizi yang tinggi serta murah yang dapat dinikmati oleh semua kalangan masyarakat. Nilai konsumsi sumber pangan ini mencapai $0,2262 \mathrm{~kg}$ konsumsi per kapita seminggu di Kota Cimahi. Industri tahu/tempe sendiri merupakan industri kecil atau rumah tangga yang banyak tersebar di seluruh wilayah Indonesia, termasuk di Jawa Barat, khususnya Kota Cimahi. Data Dinas Perdagangan, Koperasi, UKM dan Perindustrian Kota Cimahi menunjukkan bahwa sebesar $29,63 \%$ dari industri pengolahan pangan adalah industri pengolahan tahu/ tempe.

Proses pembuatan tahu di Indonesia, khususnya Kota Cimahi masih menggunakan metode tradisional. Dalam proses produksinya, diperlukan bahan baku air untuk mencuci kacang kedelai dan merebus kacang kedelai 
hingga proses pembuatan tahu selesai. Hal ini menghasilkan jumlah limbah yang cukup banyak. Dari beragam persoalan limbah dan relevansinya dengan pemanfaatan limbah, salah satu isunya yaitu penanganan dan pengelolaan limbah hasil industri kecil pembuatan tahu (Nasir dan Fatkhurohman, 2010).

Limbah cair yang dihasilkan dari industri kecil tahu di berbagai daerah potensial untuk dikembangkan menjadi energi alternatif untuk pemenuhan kebutuhan kegiatan rumah tangga dan lainnya (Darsono, 2007; Damayanti, et al., 2004). Saat ini sebagian besar industri tahu rumah tangga tidak dilengkapi dengan unit pengolah air limbah dikarenakan keterbatasan dana dan pengetahuan. Hal tersebut tentu saja menyebabkan pencemaran lingkungan sekitar lokasi industry, terutama pencemaran air yang berakhir di sungai.

Data Chemical Oxygen Demand (COD) menunjukkan bahwa sungai Cimahi tercemar limbah industri sebanyak 94,91 persen, 4,81 persen dari limbah domestik (Republika.co.id, 2017).

Penanganan dan pengelolaan limbah hasil produksi industri sangat urgen agar tidak menimbulkan limbah yang rentan terhadap lingkungan, baik berupa limbah cair, padat atau bentuk limbah lainnya. Oleh karena itu, edukasi kepada pelaku usaha industri kecil terkait masalah penanganan dan pengelolaan limbah hasil usaha sangat penting (Nasir dan Fatkhurohman, 2010).

Solusi sederhana untuk memperbaiki hal tersebut ialah dengan memberikan sosialisasi dan pengetahuan mengenai bagaimana cara membuat alat pengolah limbah sederhana yang dapat diterapkan pada industri tahu skala kecil/ rumah tangga di Kota Cimahi.

Pada dasarnya, limbah cair yang dihasilkan dari hasil pemerasan ampas tahu, dapat diolah menjadi pupuk cair organik yang dapat dimanfaatkan dalam bidang pertanian. Hasil perasan tahu yang dihasilkan yaitu berupa ampas tahu, saat ini masih mengandung air yang cukup banyak sehingga bila ampas tahu ini dijual langsung kepada peternak, para peternak masih memerlukan proses pengeringan sebelum dijadikan sebagai campuran pakan ternak. Apabila ampas tahu ini diolah kembali agar kandungan airnya berkurang, hal tersebut akan menjadi manfaat tersendiri bagi pelaku usaha tahu dan peternak. Air dari perasan ampas tahu pun akan lebih banyak sehingga dapat dijadikan pupuk cair organik yang lebih melimpah. Namun, hingga saat ini, pelaku usaha tahu belum memiliki alat yang berfungsi sebagai alat press ampas tahu yang lebih maksimal. Modal, menjadi salah satu kendala. Kurangnya pengetahuan akan manfaat lebih dari limbah cair tahu juga menjadikan pelaku usaha enggan mengolah limbah cair tahu lebih lanjut lagi.

Selain menjadi makanan ternak, ampas tahu yang dihasilkan pada dasarnya masih dapat dijadikan sebagai produk makanan karena di dalamnya masih terkandung gizi yang tidak kalah bermanfaat dari produk tahu itu sendiri.

Ditinjau dari komposisi kimianya, ampas tahu bisa digunakan sebagai sumber protein. Ampas tahu lebih tinggi kualitasnya dibandingkan dengan kacang kedelai. Prabowo dalam Gustina 
(2016) menyatakan bahwa protein ampas tahu memiliki nilai biologis lebih tinggi daripada protein biji kedelai dalam keadaan mentah, karena bahan ini berasal dari kedelai yang telah dimasak. Ampas tahu juga mengandung unsur-unsur mineral mikro maupun makro yaitu untuk mikro; $\mathrm{Fe}$ 200-500 ppm, Mn 30-100 ppm, Cu 5-15 ppm, Co kurang dari $1 \mathrm{ppm}, \mathrm{Zn}$ lebih dari 50 ppm.

Ampas tahu akan bernilai lebih tinggi bila dapat diolah menjadi jenis produk lanjutan dibandingkan hanya untuk pakan ternak. Hal ini tentu saja menjadi peluang pasar yang baru bagi pelaku industri tahu itu sendiri, maupun masyarakat di sekitar pabrik yang dapat melihat peluang bisnis produk ampas tahu ini. Tentu saja hadirnya ide produk baru dari ampas tahu ini perlu didukung dengan pengetahuan mengenai strategi pemasaran yang benar oleh pelaku industri maupun masyarakat yang ingin mengembangkan usaha ini.

Adapun tujuan dari program kegiatan ini adalah sebagai berikut,

a. Memberikan pengetahuan tentang proses pengolahan limbah cair yang lebih baik kepada pelaku industri tahu.

b. Memberikan pengetahuan mengenai pembuatan alat pengolah limbah tahu sederhana.

c. Memberikan pengetahuan tentang manfaat lebih dari ampas tahu hasil proses produksi.

d. Memberikan kemampuan bagaimana cara memasarkan produk baru dari ampas tahu kepada pelaku usaha tahu maupun masyarakat sekitarnya.

\section{METODE}

\section{Tahap Sosialisasi dan Riset Pasar}

Tahap sosialisasi, riset pasar dan penyuluhan ini dilaksanakan dalam rentang waktu tanggal 30 Agustus hingga 13 Oktober 2017. Adapun kegiatan yang dilakukan pada tahap ini adalah dimulai dari rapat koordinasi dengan Dinas Koperasi dan UMKM serta pendamping UMKM Kota Cimahi bertempat di Cimahi Technopark. Selanjutnya, tim melakukan riset pasar guna mendapatkan gambaran mengenai kondisi pasar untuk produk dari industri tahu serta melakukan kunjungan lapangan ke pabrik tahu guna mengetahui sejauh mana system pengolahan limbah tahu saat itu. Setelah mengumpulkan data yang diperlukan, tim menyusun bahan sosialisasi untuk proses selanjutnya yaitu penyuluhan mengenai program yang akan diadakan kepada pelaku industri tahu dan masyarakat sekitar yang berminat. Seminar telah diadakan pada tanggal 7 Oktober 2017 bertempat di Aula Kecamatan Cimahi yang dihadiri oleh pihak dari Dinas Koperasi dan UMKM Kota Cimahi, pendamping UMKM Kota Cimahi, pelaku usaha tahu dan tempe.

\section{Tahap Penyuluhan dan Pelatihan}

Setelah seminar berlangsung satu kali dalam waktu satu hari, program dilanjutkan dengan mengunjungi pelaku usaha pembuatan tahu di Kel. Cipageran guna mendapatkan informasi apakah hasil dari seminar yang telah dilaksanakan dapat ditindaklanjuti. Pada tahap ini diketahui adanya keinginan dari pelaku industri tahu untuk 
DIFUSI

Volume 2, No.1 Januari 2019

memasang alat pengolah limbah tahu sederhana yang sebelumnya telah disosialisasikan. Lebih lanjut pelaku usaha tersebut juga tertarik untuk memanfaatkan limbah ampas tahunya untuk membuat produk kreatif dan unik.

\section{Tahap Evaluasi}

Adapun dalam tahap evaluasi ini uji coba alat pengolah limbah sederhana pada pengolahan ampas tahu dilaksanakan dengan pengukuran kandungan air dari ampas tahu tersebut. Dalam hal pelatihan strategi pemasaran dilakukan dengan menggunakan teknik wawancara dan diskusi setelah produk dari ampas tahu terbentuk.

\section{HASIL DAN PEMBAHASAN}

\section{Pelatihan Pembuatan Produk Nugget Ampas Tahu}

Alat pengolah limbah tahu yang telah dibuat dan diaplikasikan di industry tahu terbukti dapat menghasilkan ampas tahu dengan kandungan air yang lebih sedikit. Hal ini membuat ampas tahu tersebut menjadi lebih kering sehingga mudah diolah. Dari ampas tahu tersebut, dibuatlah sebuah produk baru dalam bentuk makanan yaitu nugget. Produk nugget ampas tahu ini menjadi salah satu strategi diversifikasi produk yang dapat dilakukan oleh pelaku usaha pembuatan tahu yang selama ini hanya memproduksi produk tahu original saja. Nugget ampas tahu ini juga dapat diproduksi oleh kelompok masyarakat sekitar pabrik tahu yang dapat memanfaatkan limbah bersih ampas tahu tersebut.
Proses pembuatan nugget ampas tahu dilakukan mulai dari membuat resep yang enak hingga membuat nugget ampas tahu yang siap untuk dikonsumsi dalam kemasan yang menarik sehingga mempunyai daya tarik jual yang baik.

Setelah nugget ampas tahu berhasil dibuat, para peserta diberikan pengetahuan bagaimana cara mengemas dan membuat label untuk produk nugget ampas tahu yang baik dan menarik. Kemasan yang ditawarkan terdapat dua jenis kemasan yaitu wrap plastic dan kemasan kotak (dapat dilihat pada Gambar 1). Kemasan wrap plastic sendiri mempunyai kelebihan yaitu bila konsumen tidak ingin langsung menggoreng seluruh potongan nugget ampas tahu, maka wrap plastic nugget dapat ditutup kembali dengan mudah dan disimpan di dalam lemari es. Begitupun dengan kemasan plastik kotak yang dapat ditutup dan dibuka kembali.

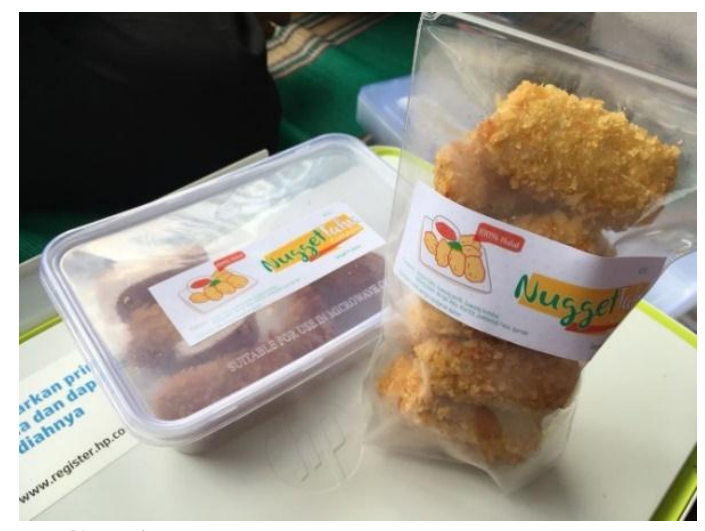

Gambar 1. Kemasan Nugget Ampas Tahu

Setelah dikemas, diberikanlah informasi mengenai cara membuat label yang baik dan menarik untuk produk nugget ampas tahu tersebut. Label yang diberikan menggunakan kertas stiker yang dapat di print sendiri oleh para 
peserta. Adapun bahan lain yang dapat digunakan oleh pelaku usaha yaitu menggunakan kertas HVS biasa yang lebih murah daripada kertas stiker. Untuk isi label itu sendiri terdiri dari nama produk yang dijual yaitu Nugget Ampas tahu, kemudian keterangan komposisi bahan produk, tanggal produksi, berat bersih, keterangan produsen, keterangan halal, dan izin daftar edar produk. Akan tetapi, dikarenakan ini adalah produk baru, dan belum memiliki izin usaha dan izin edar lainnya, maka keterangan tersebut masih dikosongkan. Adapun gambaran label tersebut dapat dilihat pada Gambar 2.

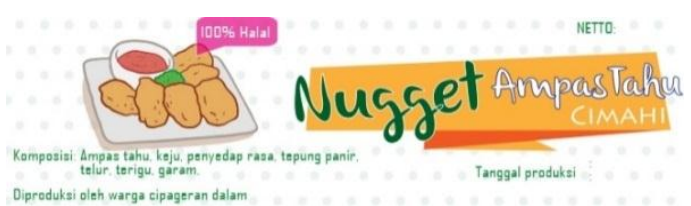

Gambar 2. Design Label Produk Nugget Ampas Tahu

Setelah menjadi produk yang siap jual, para peserta mencoba produk nugget ampas tahu yang telah dibuat dan membagikannya kepada para warga sekitar untuk melihat respon dari calon konsumen. Dari semua orang yang mencoba, mereka mengatakan bahwa mereka tidak menyangka bahwa ampas tahu dapat diolah menjadi makanan yang sangat enak seperti ini. Masyarakat yang mencicipi pun tertarik untuk bisa membeli bahkan membuat produk nugget ampas tahu ini. Kelompok masyarakat setempat juga tertarik untuk membuat usaha dari produk ampas tahu ini karena bahan baku dapat diperoleh dengan mudah dan murah serta cara pembuatan yang cukup mudah dilakukan. Modal yang diperlukan untuk memulai usaha ini juga tidak terlalu besar yaitu tidak lebih dari Rp 2.000.000,- dengan asumsi bahwa peralatan memasak sudah dimiliki sebelumnya.

\section{Pelatihan Strategi Pemasaran Produk Nugget Ampas Tahu}

Dari segi strategi pemasaran, tim pengabdian memberikan pelatihan khusus berkenaan dengan pemasaran online yang dapat dilakukan oleh para peserta yang rata-rata adalah ibu rumah tangga. Pertama-tama, diberikan teori pemasaran secara umum yaitu tentang produk, tempat, harga, dan promosi. Sebelum memasarkan produk melalui Internet atau secara online melalui sosial media, diperlukan persiapan produk yang matang, seperti dalam hal kemasan dan foto produk yang berkualitas. Dalam pelatihan tersebut, tim pengabdian mengajarkan bagaimana cara menghasilkan foto produk berkualitas baik seperti foto studio tetapi dengan modal hanya smartphone yaitu dengan memfoto produk kita pada saat pagi hari sekitar jam 9 - 10 pagi dan/atau jam $3-4$ sore hari ketika cuaca cerah.

Setelah teori singkat mengenai pemasaran dipaparkan, selanjutnya diberikan pelatihan bagaimana cara memulai memasarkan produk melalui Internet degan menggunakan sosial media. Pertama kali adalah diperlukan alamat email untuk mendaftarkan halaman produk nugget ampas tahu ke semua sosial media. Maka tim pengabdian membuatkan email yang beralamat di ampastahu.cimahi@gmail.com sebagai alamat email produk nugget ampas tahu. 
DIFUSI

Volume 2, No.1 Januari 2019

Setelah membuat email usaha, kemudian mempraktikan dan memperlihatkan bagaimana cara membuat halaman bisnis pada situs Facebook.com (Gambar 3). Tim pengbadian mendemonstrasikan bagaimana cara memposting berita dan foto untuk mempromosikan produk nugget ampas tahu.

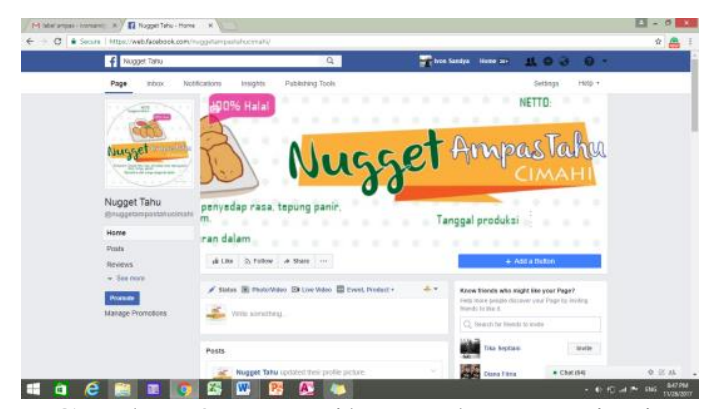

Gambar 3. Tampilan Halaman Bisnis

Facebook Produk Nugget Ampas Tahu

Selain membuat halaman bisnis di situs Facebook.com, kemudian kami mencontohkan cara membuat akun bisnis pada media sosial Instagram (Gambar 4). Dari akun Instagram Nugget Ampas Tahu Cimahi ini, kami memberitahukan cara bagaimana untuk mempromosikan produk mereka melalui fasilitas Instagram Ads melalui halaman business.instagram.com. Banyak dari peserta yang belum mengetahui tentang fasilitas ini dan ingin lebih lanjut untuk mengetahui bagaimana cara kerja dari fasilitas Instagram Ads ini. Instagram Ads ini sendiri adalah salah satu fasilitas yang dapat pelaku usaha pakai untuk mengiklankan produk mereka di Instagram dengan target pasar yang dapat dipilih sesuai dengan produk yang dijual. Walaupun fasilitas ini berbayar sekitar Rp 50.000/ 24 jam, tetapi bila diperhitungkan secara maksimal maka dapat menghasilkan keuntungan yang cukup tinggi.

(2) 专苗

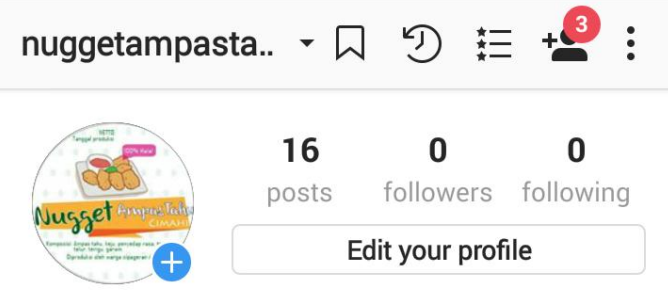

Nugget Ampas Tahu Cimahi

Produk Inovasi dari Ampas Tahu

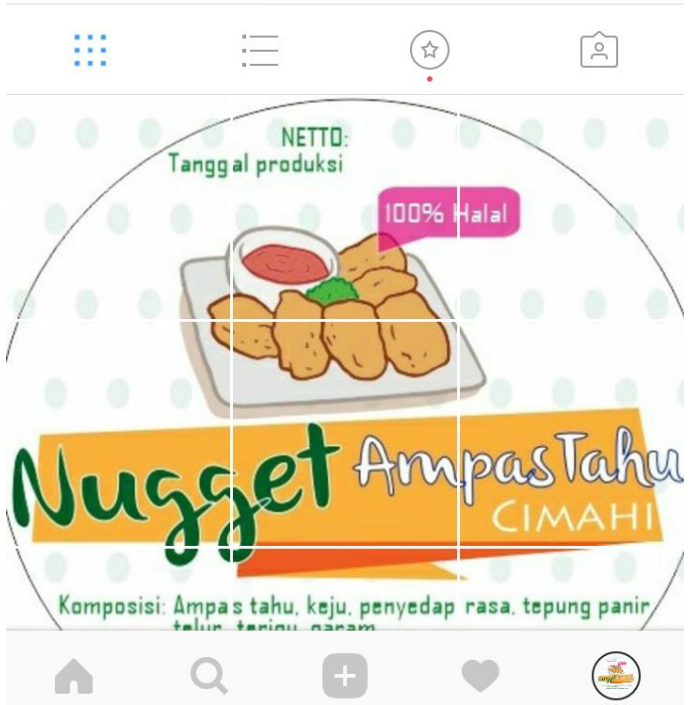

Gambar 4. Tampilan Akun Instagram

Produk Nugget Ampas Tahu

Setelah berdiskusi lebih lanjut mengenai pemasaran dan beriklan melalui media sosial Facebook dan Instagram, tim melanjutkan pelatihan dengan memberikan informasi mengenai pendukung menjalani bisnis rumah tangga dengan memanfaatkan GO FOOD dari GOJEK Indonesia. GO FOOD sendiri adalah salah satu layanan yang diberikan oleh PT. GOJEK Indonesia yang melayani jasa antar makanan kepada para pengguna jasa layanan pada aplikasi GOJEK. GO 
DIFUSI

Volume 2, No.1 Januari 2019

FOOD telah bekerjasama dengan banyak tenant restaurant dan usaha makanan lainnya, dan tetap membuka peluang kerjasama bagi para pengusaha kuliner yang bergabung menjadi bagian dari GO FOOD. GO FOOD menjadi alternative yang terbaik saat ini bagi pelaku usaha rumahan yang belum mempunyai tempat yang cukup strategis untuk memasarkan produk dan tidak mempunyai jasa layanan antar makanan. Tim memberikan contoh bagaimana cara bergabung dengan GO FOOD melalui halaman situs resmi PT. Gojek Indonesia.

\section{KESIMPULAN}

Kegiatan program pengabdian kepada masyarakat dengan tema pembuatan alat pengolah limbah tahu sederhana dan strategi pemasaran produk industri tahu di Kelurahan Cipageran Kota Cimahi secara umum dapat dilaksanakan dan berjalan dengan baik.

Kegiatan yang telah dilaksanakan secara umum telah memberikan pengetahuan dan informasi kepada masyarakat sekitar Kelurahan Cipageran dan pelaku usaha pembuatan tahu khususnya tentang alat pengolah limbah tahu sederhana dan bagaimana cara membuat produk inovasi dari ampas tahu serta cara pemasarannya.

Kegiatan yang telah dilaksanakan akan lebih efektif lagi bila didukung dengan komitmen, semangat dan motivasi yang tinggi dari para peserta serta fasilitas yang menunjang. Oleh sebab itu saran untuk kegiatan selanjutnya, diharapkan program ini dapat memberikan motivasi lebih pada masyarakat yang terlibat.

\section{UCAPAN TERIMAKASIH}

Terimakasih kepada para pihak yang telah ikut mendukung dan membantu terlaksananya program kegiatan pengabdian kepada masyarakat ini seperti Dinas Koperasi dan UMKM Kota Cimahi, pendamping UMKM Kel. Cipageran Kota Cimahi, pelaku industri tahu Bapak Alpian, dan masyarakat di Kel. Cipageran yang telah aktif dalam mengikuti program kegiatan ini. Kegiatan ini juga telah berjalan lancar tidak luput dari dukungan institusi Politeknik Negeri Bandung sebagai pendukung dalam dana operasional suksesnya kegiatan ini.

\section{REFERENSI}

[1] BPS Cimahi. (2015). Produk Domestik Regional Bruto Kota Cimahi Provinsi Jawa Barat Menurut Lapangan Usaha 20112015. BPS Kota Cimahi. Cimahi.

[2] Damayanti, A., Hermana, J., \& Masduqi, A. (2004). Analisis Resiko Lingkungan dari Pengolahan Limbah Pabrik Tahu dengan Kayu Apu (Pistia stratiotes L.). Jurnal Purifikasi, 5(4), 151-156.

[3] Darsono, V. (2007). Pengolahan Limbah Cair Tahu Secara Anaerob dan Aerob. Jurnal Teknologi Industri, 11(1), 9-20.

[4] Hidayat, A. W. (2015). Identifikasi Faktor Internal dan Eksternal Penyebab Kegagalan Usaha Pada Industri Tahu di Kelurahan Citeureup Kota Cimahi (Studi Kasus Pada Usaha Tahu di Kampung Sukaresmi Tahun 
DIFUSI

Volume 2, No.1 Januari 2019

2014). e-Proceeding of Management, 2(1), 53-60.

[5] Khalil, N., \& Khan, M. (2009). A case of municipal solid waste management system for a medium-sized Indian City, Aligarh. Management of Environmental Quality: An International Journal, 20(2), 121141.
[6] Ridwan, M. F. (2017). http://www.nasional.republika.co.i d. Diakses Tanggal 28 Januari 2017

[7] Suparyanto, R. (2012). Kewirausahaan : Konsep dan Realita Usaha Kecil. Alfabeta. Bandung 